\title{
Students' prior knowledge and threshold concepts in a first-year biology course: The lecturer as middleman
}

\author{
Shalini Dukhan \\ University of the Witwatersrand \\ Corresponding Author: Shalini.dukhan@wits.ac.za
}

(Submitted: 1 October 2020; Accepted: 8 September 2021)

\begin{abstract}
Constructive alignment focuses on alignment between curriculum, learning outcomes, teaching activities, and assessment. This study argues that for lecturers to set intended learner-centred outcomes, they need insight into students' prior knowledge of a discipline's threshold concepts. Little is known about how a syllabus's assumptions of prior knowledge match up to what firstyear students know. Yet this insight is necessary; new knowledge is built on existing knowledge, and learning is about moving to higher cognitive levels. To gain this insight, at the start of the 2018 academic year, 292 first year biology students voluntarily answered two formative, online multiple-choice assessments on DNA and RNA synthesis. The responses showcased their knowledge gaps versus what the syllabus expected. Data analysis of their responses was used to shape teaching activities. This study extends constructive alignment by showing how quality teaching in content-dense disciplines such as biology further requires that lecturers gauge students' prior knowledge.
\end{abstract}

Keywords: constructive alignment, curricular adaptation, first-year preparedness for university, lecturer practice, multiple-choice assessments, students' prior knowledge

\section{Introduction}

In South Africa there are differing levels of student preparedness for university, and factors external to the student can influence preparedness (Sobuwa and McKenna, 2019). First-year cohorts come from a range of school backgrounds and thus learning experiences, and this background experience is one external factor that could impact on preparedness (Dukhan, 2018). For quality teaching and learning to occur within university classrooms, there is a need for lecturers to be aware of gaps that might exist between first-year students' prior knowledge, and the knowledge the prescribed syllabus presumes (Wang, et al., 2013).

Constructive alignment (Biggs, 1996; Biggs and Tang, 2007) illustrates the intricate association between learning outcomes in the intended curriculum (or prescribed syllabus), teaching and learning activities, and assessment. One of the foundations of constructive alignment, as presented by Biggs (1996), is that teachers should view students' conceptions from 
their learners' perspective, and any alternative or erroneous understandings should allow for cognitive development. However, few studies within the context of biology teaching indicate how this can be accomplished. This study examines how lecturers' insights into student knowledge, in terms of the syllabus's expectations, could shape teaching practice, and thereby provide closer alignment between the students' needs and the syllabus.

This study focuses on a large first-year biology class, i.e., approximately 450 students that I teach. Biology is a content-heavy discipline where abstractions are a norm, therefore lecturers need to find approaches to assist students with making meaning of the content presented in the classroom (Armbruster, et al., 2009). As a lecturer, I have observed that while some students are knowledgeable about the foundational terminology and concepts in the first-year prescribed syllabus, others were not. This means there could be gaps between what students know, the expectations laid out in the syllabus, and what lecturers plan to teach based on the knowledge expected of first years. Biggs's (2003) constructive alignment theory explains that within any given course there needs to be coherence across the curriculum, teaching practices, learning outcomes, and assessments. When first-year biology classes are large and diverse (Moravec, et al., 2010), as is often the case with public higher education institutions in South Africa (Dukhan, 2018), lecturers could experience difficulty in gaining insight into students' relevant prior knowledge of threshold concepts that need to be built on during teaching (Kelly-Laubscher and Van Der Merwe, 2015).

A threshold concept is a form of knowledge that enables access to fundamental concepts, and students reposition themselves in terms of these concepts as they consider how new knowledge influences prior knowledge (Meyer and Land, 2005). For lecturers to guide this process of learning, it is necessary to understand the depth of prior knowledge students have in relation to threshold concepts (Dennick, 2016).

In biology, accessing threshold concepts often requires visualising intangible, abstract and complex processes and structures: An example is the process of DNA (deoxyribonucleic acid) or RNA (ribonucleic acid) replication and protein synthesis, which is notoriously difficult for students to grasp (Wright, et al., 2014). For lecturers to bridge the gap between what students know, and what first years are presumed to know based on the prescribed syllabus, lecturers need to have insight into students' prior understandings of this concept. One way to gain this insight is to use low-stakes formative tests (Baird, et al., 2017).

The use of online multiple-choice tests is an efficient way to gauge student understanding under time and large-class constraints (Kelly-Laubscher and Van Der Merwe, 2015; Morrison and Free, 2001). Lecturers can use their critique of student responses to the assessments to fine-tune their teaching. This can occur once lecturers see the extent to which students understand threshold concepts related to the new knowledge that will be taught, and the errors they make (Hattie, 2015). To consider the usefulness of this approach, this study addresses the research question: 'How can student responses to online multiple-choice tests in biology provide the lecturer with quick insight into the prior knowledge first years have in relation to threshold concepts about DNA and RNA?' 
This paper proposes that first-year students' responses to online multiple-choice assessments could help lecturers identify problem areas that could impact on the students' grasp of threshold concepts. The theory on constructive alignment suggests that teachers get learners to engage in activities appropriate to their current knowledge structure, but the theory does not speak about what teachers need to do to gain this insight. This paper contributes towards addressing this gap by examining a way in which the responses to online tests that students complete, early in the year, could function as the lecturers' tools to 1) gain insight into the depth of student understanding relative to threshold concepts of DNA and RNA in the syllabus, 2) aid in customising pedagogy according to their students' needs by building on their prior knowledge, and 3) show how the use of online multiple-choice tests can facilitate constructive alignment within the course.

\section{Literature Review and Conceptual Framework}

Constructive alignment describes the interconnection of learning outcomes in the intended curriculum, teaching and learning activities, and assessment (Biggs and Tang, 2007). This constructivist theory is founded on the perspective that learners oversee their own learning, and that teachers mediate this process by designing activities that enable students to actively participate in their learning (Biggs, 2003).

Biggs (2003) identifies four stages to constructive alignment. Firstly, setting intended learning outcomes; secondly, choosing teaching and/or learning activities aligned to these outcomes, thirdly, assessing learners' needs to determine the extent of learning in relation to the outcomes; and lastly, establishing a final grade for learners. Biggs warns that teaching and assessment need to be at the appropriate level to ensure learning equilibrium. When curriculum and assessment needs are met, classroom instruction benefits. The question that emerges then is: If large first-year classes are diverse in terms of student preparedness for university, what could be done to provide an enriched learning environment in relation to constructive alignment as outlined by Biggs? This study builds on Biggs's notion to demonstrate that when teachers understand their students' needs, they can design curricular and assessment requirements to achieve better alignment.

Furthermore, the study proposes one more step for Bigg's alignment to occur: Teachers need to have insight into the prior foundational knowledge that students have when they enter a course. Without this level of awareness, it is possible that learning activities could be set at either higher or lower cognitive levels than needed to achieve the curriculum's learning outcomes. If learning activities are targeted at higher than required cognitive levels, it is possible that students would not have the necessary knowledge structures to be able to tackle the tasks. If learning activities are set at lower than required cognitive levels, there would be little development of learning. Thus, for constructive alignment to occur, lecturers need to be aware of their students' prior knowledge.

The intended curriculum in the form of the syllabus can make the relevant prior knowledge and threshold concepts visible to students (Wang, et al., 2013). It is therefore necessary for 
lecturers to determine the extent to which these knowledge areas and concepts are explicit in the syllabus (Kember and Kwan, 2000). Literature on teaching and learning activities show that assessment can be used to measure learning gains, i.e., 'assessment of learning', while assessment practices could also be used as a tool to encourage learning, here literature describes 'assessment for learning' as well as 'assessment as learning' (Boud and Falchikov, 2007; Carless, 2015). My study focuses on assessment as a tool to aid instructional design. The focus is on how students' responses to online multiple-choice tests on their prior knowledge can be used to shape lecture content and delivery on DNA and RNA.

When constructive alignment is considered during curriculum design, it can support a deep approach to learning (Wang, et al., 2013). The teaching activities that are considered and planned during instructional design should prompt learners to consider how new knowledge fits into what they already know. Ambrose and Lovett (2014) explain that students who exhibit a surface approach to their learning, and repeatedly invest effort using the same technique, are often left wondering why their academic performance does not improve; but when a deep approach to learning is applied, the learning process becomes meaningful (Hattie and Yates, 2014). This study contributes to literature by examining a practical approach that lecturers can use to meaningfully shape teaching practice, and presents a mechanism to facilitate lecturer practice and pedagogy.

\section{The relevance of prior knowledge and threshold concepts to teaching and learning}

When prior knowledge is correct it facilitates the comprehension of new concepts and the development of new skills (Van den Broek and Kendeou, 2008). When prior knowledge is incorrect, students tend to discount the new knowledge that conflicts with their current knowledge. This is where the students' responses to multiple choice tests could expose gaps in their understandings (Van Loon, et al., 2015). In contexts such as South Africa where first years come into university from a diversity of school backgrounds and thus levels of preparedness, it is crucial to determine how students could be catered for within the large class, biology setting. South Africa now has opportunities for a diversity of students to access higher education, and this study seeks to contribute towards pedagogic practice that could scaffold their academic success.

When lecturers identify gaps in prior knowledge among students and then prepare instructional material accordingly, students connect better what they already know to the new content provided (Ambrose and Lovett, 2014). This research proposes that instructors identify the level of relevant prior knowledge by providing tests that are linked to threshold concepts to be taught for the course, as this illuminates their prior knowledge. Students do not usually engage with the syllabus when preparing for class in ways that lecturers expect (Richmond, et al., 2016), which means that students might not necessarily be aware of the content they need before the lecture. Based on their learning experiences at high school, many students have not developed the know-how to use a syllabus when they enter first year (Kelly-Laubscher and Van Der Merwe, 2015). 
It is necessary for first-year lecturers to understand the students' quality of prior knowledge so that there is no misconception of threshold concepts being understood. Concepts within biology are difficult for students to visualise because abstractions are usually required to understand biological processes (Wright, et al., 2014). Threshold concepts could act as gatekeepers for more complex material to be understood meaningfully. For instance, to understand the process of DNA replication and protein synthesis, it is necessary to first have a firm prior understanding of the structure and function of the different parts that make up DNA and RNA. Without this, little meaning would be gained when attempting to elucidate how DNA replication and protein synthesis work (Coley and Tanner, 2015; Prevost, et al., 2016). It is therefore necessary for lecturers to establish what the gaps in prior understanding are before moving into more complex areas of the syllabus.

\section{The use of online tests to uncover students' depth of prior knowledge}

It is useful for lecturers to identify the quality of students' background understanding of topics related to the syllabus so that any gaps in prior knowledge can be incorporated into instructional design. One way that lecturers can identify students' depth of understanding early on is with online tests (Baleni, 2015). Using these tests as an aid to lecturers' preparation for class has not received much attention in literature but as this paper will show, it is a valuable lecturer-led strategy that promotes student learning.

Constructive alignment is critical when designing how to make abstract concepts visible to first years, especially in content-dense disciplines. This study sheds light on this alignment and contributes to current literature through introducing how students' responses to online multiplechoice tests early in the year can be used to shape lecture preparation for large and diverse biology classes.

\section{Methods}

The first-year 'Introduction to Medical Biology' syllabus was examined to determine what threshold concepts students were expected to know for the topics, DNA and RNA synthesis.

This research was conducted in 2018 within a first-year medical biology course at a South African university. Sections on DNA and RNA were taught over a four-week period, with two weeks dedicated for each of these topics. Each week, students were provided with four 45-minute lectures; one two-hour practical laboratory session; and one 45-minute tutorial. There were approximately 450 students registered for the course, 292 first years participated on two online assessments at the beginning of the year, i.e., ahead of the start of teaching. Respondents were $46 \%$ female and $54 \%$ male. The class answered the online tests on a voluntary basis, it was not a compulsory aspect of the course.

The test questions were selected from the test bank made available by the publishers of the prescribed textbook. Each test consisted of 30 questions, i.e., 60 questions in total. The first test focused on knowledge that students were expected to know on DNA replication, and the second test was on RNA and protein synthesis. All tests comprised multiple-choice questions 
only. The tests were provided on the university's online learning platform. Each test was set to be completed within a 45-minute period. Only questions considered as part of prior-knowledge, as noted in the first-year syllabus, were included.

The lecturer analysed the test questions to gain a concrete impression of the depth of understanding and relevant fundamental knowledge that would be expected of the students for each question, and the extent to which the syllabus's expectations were accurate. Additionally, the lecturer analysed student responses to test questions to determine the extent of their prior knowledge of the topics.

Table 1 depicts the rubric used to analyse test questions. Cognitive abilities are defined at the structural, conceptual and procedural level, and show an increase in mental abilities as one moves up each of these cognitive levels. Part of the analysis was to rank test questions according to whether they required students to recall, understand or apply information, or to analyse data. Examples of these types of questions are provided below in the methods section and in the results section.

There were two dimensions to the analysis of the test questions (Table 1).

Table 1: Rubric showing the hierarchy of cognitive levels and knowledge dimensions that were assessed by means of the test questions

\begin{tabular}{|c|c|c|c|c|c|}
\hline & & \multicolumn{4}{|c|}{ COGNITIVE LEVELS } \\
\hline & & $\begin{array}{l}1 \\
\text { Recall }\end{array}$ & $\begin{array}{l}2 \\
\text { Understanding }\end{array}$ & $\begin{array}{l}3 \\
\text { Analysis }\end{array}$ & $\begin{array}{l}\text { Total per } \\
\text { knowledge } \\
\text { dimension }\end{array}$ \\
\hline \multirow{4}{*}{ 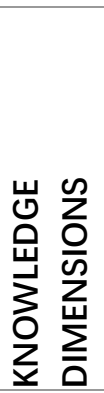 } & $\begin{array}{l}\text { Factual knowledge } \\
\text { (F) }\end{array}$ & & & & \\
\hline & $\begin{array}{l}\text { Conceptual } \\
\text { knowledge (C) }\end{array}$ & & & & \\
\hline & $\begin{array}{l}\text { Procedural } \\
\text { knowledge (P) }\end{array}$ & & & & \\
\hline & $\begin{array}{l}\text { Total per cognitive } \\
\text { level }\end{array}$ & & & & \\
\hline
\end{tabular}

The first dimension, which represents the required cognitive level, has a scale of 1-3, where:

1 = Recall; 2 = Understanding; 3 = Analysis.

The second dimension represents the different knowledge dimensions, where:

$\mathrm{F}=$ Factual knowledge (facts were required to answer the question); $\mathrm{C}=$ Conceptual knowledge (concepts/processes/theories were being tested); $\mathrm{P}=$ Procedural knowledge (students were required to do a calculation/interpret a graph or diagram)

Examples:

1. DNA replication is said to be semiconservative. What does this mean?

- Half of the old strand is degraded and half is used as a template for the replication of a new strand.

- One of the two resulting double helices is made of two old strands, and the other strand is made of two new strands. 
- One strand of the new double helix is made of DNA and the other strand is made of RNA.

- Each new double helix consists of one old and one new strand.

- The old double helix is degraded and half of its nucleotides are used in the construction of two new double helices.

This was categorised as F1 i.e., factual recall of knowledge.

2. One strand of a DNA molecule has the base sequence 5'-ATAGGT-3'. The complementary base sequence on the other strand of DNA will be 3'$-5$

- tgGauA

- UAUCCA

- tATCCA

- tgGata

- $\quad$ ATAGGT

This was categorised as F3 i.e., factual, but requiring analysis.

3. DNA is a self-replicating molecule. What accounts for this important property of DNA?

- The nitrogenous bases of the double helix are paired in specific combinations A with T and $\mathrm{G}$ with $\mathrm{C}$.

- Its two strands are held together by easily broken covalent bonds.

- Replication is thermodynamically spontaneous and requires no enzymes.

Here students had to show an understanding of concepts, thus this was categorised as C2.

4. Meselson and Stahl grew bacteria in a medium containing 'heavy' radioactive nitrogen $(13 \mathrm{~N})$ and then transferred them to a medium containing $14 \mathrm{~N}$ (non-radioactive). Which of the results in the figure would be expected after one round of DNA replication in the presence of $14 N$ ?

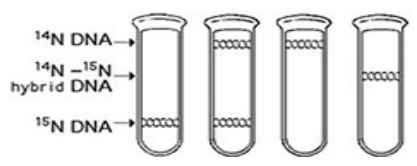

A $\quad$ B $\quad C *$ D

This question required students show their understanding of a process with the aid of a diagram and was categorised as P3.

The data were analysed inductively by qualitative analysis. According to Braun and Clarke (2006), thematic analysis is used to examine people's realities, and acknowledges the way in which individuals construct meaning. Thematic analysis was used to analyse the prior knowledge students were expected to have for each topic in accordance with the prescribed syllabus. Codes that emerged from initial reading of the data were built on during the data analysis process. The coded data were compared to the knowledge that students had when they entered the course (i.e., test responses). Analysis was based on the extent to which the students' prior knowledge 
was aligned to the content of the syllabus, and the depth of understanding students had when they were required to apply knowledge to problems which needed higher order cognitive reflection. Results from the test responses were examined in relation to the threshold concepts presented in the syllabus for DNA and RNA synthesis. The content indicated as fundamental knowledge as listed on the syllabus was entered onto MAXQDA (version 18.2.4), a qualitative software programme, to thematically analyse the data. The comparative, qualitative analysis enabled the elucidation of concepts that students were struggling with in terms of their depth of understanding.

Ethics clearance was granted by the University's Ethics Committee (protocol number 2019ECE001PG).

\section{Results and Analysis}

This study focused on examining the students' responses to tests to gain insight into their prior knowledge. The results were then used to mould a curriculum to their needs. The main finding showed that although students recalled content related to threshold concepts, they were rarely able to apply this knowledge when assessed at higher cognitive levels. Moreover, it was evident that the expectations of prior knowledge as set out by the intended curriculum were a mismatch to the actual knowledge students possessed when they started the course. This means that pedagogic practice was needed to deliberate on ways to help students learn to apply the knowledge that they remembered so that they could get a good grasp of threshold concepts prior to the lecturer moving onto the more complex aspects of the syllabus.

According to constructivism, learners actively select the knowledge with which they will engage and build on their foundational knowledge as they consider how the new knowledge fits into this structure (Biggs, 1996). In the context of the findings from my study and in terms of constructive alignment, lecturers need to be aware of the prior knowledge of students. This insight could enable lecturers to design teaching activities that are accessible in assisting students to achieve the intended outcomes.

\section{The prior knowledge specified by the syllabus}

The first-year biology syllabus noted the concepts considered as prior knowledge for each topic. While some of this background knowledge was explicitly listed, analysis of the syllabus revealed that unlisted material was also implicitly required as prior knowledge for the course (Table 2).

Students needed to understand the prior knowledge content the syllabus required both explicitly and implicitly (Table 2 ) since this provided the foundation for new content to be learnt about DNA and RNA synthesis. The theory on constructive alignment explains that learning and teaching goals need to be aimed at higher cognitive levels. My findings show that for lecturers to adequately set these levels of teaching goals, they need to be conscious of what is explicitly and implicitly required by the prescribed syllabus in relation to the students' prior knowledge. 
Table 2: Explicitly and implicitly required prior knowledge on DNA and RNA synthesis according to the prescribed syllabus

\begin{tabular}{|c|c|c|}
\hline & $\begin{array}{l}\text { Content that was explicitly noted on } \\
\text { the syllabus as prior knowledge }\end{array}$ & $\begin{array}{l}\text { Content that students were implicitly } \\
\text { required to understand based on the } \\
\text { expectations set out in the syllabus }\end{array}$ \\
\hline $\begin{array}{l}\text { DNA structure } \\
\text { and synthesis }\end{array}$ & $\begin{array}{l}\text { Explain how the process of life involves } \\
\text { the expression and transmission of } \\
\text { genetic information. }\end{array}$ & $\begin{array}{l}\text { A basic understanding of DNA structure } \\
\text { and replication. }\end{array}$ \\
\hline \multirow[t]{3}{*}{$\begin{array}{l}\text { RNA structure } \\
\text { and protein } \\
\text { synthesis }\end{array}$} & $\begin{array}{l}\text { Explain how the process of life involves } \\
\text { the expression and transmission of } \\
\text { genetic information. }\end{array}$ & $\begin{array}{l}\text { Structure of mRNA, tRNA and rRNA. } \\
\text { Basic concepts for transcription, } \\
\text { translation and protein synthesis. }\end{array}$ \\
\hline & $\begin{array}{l}\text { Explain how amino acids are grouped } \\
\text { into classes based on the characteristics } \\
\text { of their side chains. }\end{array}$ & $\begin{array}{l}\text { The structure of amino acids and } \\
\text { structural differences between these } \\
\text { molecules. }\end{array}$ \\
\hline & $\begin{array}{l}\text { Distinguish among the levels of } \\
\text { organisation of protein molecules. }\end{array}$ & $\begin{array}{l}\text { Formation of polypeptide chains in } \\
\text { translation, folding of the polypeptide } \\
\text { chain to form overall protein structure, } \\
\text { and different structural levels of proteins. }\end{array}$ \\
\hline \multirow{5}{*}{$\begin{array}{l}\text { Knowledge } \\
\text { required } \\
\text { across DNA } \\
\text { and RNA } \\
\text { structure and } \\
\text { synthesis }\end{array}$} & $\begin{array}{l}\text { Describe the components of a } \\
\text { nucleotide. Name some nucleic acids } \\
\text { and discuss the importance of these } \\
\text { compounds in living organisms. }\end{array}$ & \multirow[t]{5}{*}{$\begin{array}{l}\text { Distinguish between the nucleotides } \\
\text { found in DNA and RNA, and understand } \\
\text { the composition of each of these } \\
\text { structures. }\end{array}$} \\
\hline & $\begin{array}{l}\text { Provide labelled drawings of nucleic } \\
\text { acids. }\end{array}$ & \\
\hline & $\begin{array}{l}\text { Explain the difference between a } \\
\text { nucleotide and nucleoside. }\end{array}$ & \\
\hline & $\begin{array}{l}\text { Construct diagrams to display the } \\
\text { structure of pyrimidines and purines. }\end{array}$ & \\
\hline & $\begin{array}{l}\text { Draw the structural formula of ribose } \\
\text { and deoxyribose. }\end{array}$ & \\
\hline
\end{tabular}

Thus, lecturers should reflect on what needs to be done to support student learning in relation to the curriculum's intended learning outcomes. This reflective practice could assist with the development of teaching activities that facilitate in meeting curricular requirements. This notion connects to teachers making decisions on how the curriculum can be delivered, based on the learning needs of the student cohort, and this level of instructional design can then lead to the course being constructively aligned.

\section{The match between prior knowledge requirements listed on the syllabus and the students' understanding}

Students were expected to enter the course with prior knowledge of the syllabus's content (Table 2). Examples below illustrate that even though students came into first year being able to correctly recall foundational concepts, their depth of comprehension was not as convincing when they were required to apply this knowledge. 


\section{Comprehension of concepts on DNA synthesis}

According to the syllabus students needed to be knowledgeable about how the process of life involved the expression and transmission of genetic information (Table 2). Implicitly, this meant they needed to understand the basics of DNA structure and synthesis (Table 2). This knowledge required that they recognised the term 'template', understood the process for semiconservative replication, and were able to apply base-pairing rules.

They scored well on recall-type questions on DNA replication. $87.3 \%$ and $94.3 \%$ of respondents correctly answered examples 1 and 2 below, respectively (' $*$ ' denotes the correct response for all examples which follow):

Example 1: DNA replication is said to be semiconservative. What does this mean?

- Half of the old strand is degraded and half is used as a template for the replication of a new strand.

- One of the two resulting double helices is made of two old strands, and the other strand is made of two new strands.

- One strand of the new double helix is made of DNA and the other strand is made of RNA.

- $\quad$ Each new double helix consists of one old and one new strand.

- The old double helix is degraded and half of its nucleotides are used in the construction of two new double helices.

Example 2: Semiconservative replication involves a template. What is a template?

- An RNA molecule

- $\quad *$ One strand of the DNA molecule

- Single-stranded binding proteins

- DNA polymerase

Yet, when first years were required to provide an in-depth analysis of data for the same concept (example 3), most students selected answers that evidenced a limited understanding. $42.3 \%$ of respondents correctly answered this question which recounts how semiconservative replication would proceed when cells divide. This shows that students had difficulty applying the information for a concept they were able to recall.

Example 3: Meselson and Stahl grew bacteria in a medium containing 'heavy' radioactive nitrogen $(13 \mathrm{~N})$ and then transferred them to a medium containing $14 \mathrm{~N}$ (non-radioactive). Which of the results in the figure would be expected after one round of DNA replication in the presence of $14 \mathrm{~N}$ ?

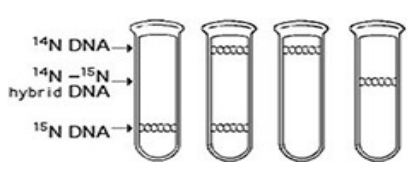

A $B \quad C *$ D 
Again, as much as students understood the core concept for semiconservative replication (examples 1 and 2), they did not yet comprehend this concept at a higher cognitive level, which required analysis and application of this knowledge (example 3). The notion of students having a surface level understanding of basic concepts, and a limited ability to apply this knowledge is further evidenced in the following two examples on DNA replication. While 95.3\% correctly answered the question which required a straightforward application of the base-pairing rule for DNA replication (example 4), their knowledge gap became evident when only $41.5 \%$ correctly answered the question that required a more intricate application of this understanding (example 5):

Example 4: One strand of a DNA molecule has the base sequence 5'-ATAGGT-3'. The complementary base sequence on the other strand of DNA will be 3'$-5^{\prime}$.

- tGgAUA

- UAUCCA

- $\quad$ *TATCCA

- tgGata

- ATAGgT

Example 5: In an analysis of the nucleotide composition of a molecule of DNA, which of the following combinations of base pairs will be found?

- $\mathrm{A}=\mathrm{C}$

- $\mathrm{G}+\mathrm{C}=\mathrm{T}+\mathrm{A}$

- $* \mathrm{~A}+\mathrm{C}=\mathrm{G}+\mathrm{T}$

- $A=G$ and $C=T$

Considering the syllabus indicated that students should have the listed prior knowledge on DNA replication (Table 2), it is noteworthy that foundational knowledge gaps existed when students were asked to apply their knowledge at higher cognitive levels. This means that there was misalignment between course expectations of prior knowledge and the reality, particularly problematic when the content is considered to contain threshold concepts to material meant to be dealt with in first year.

Like with the section on DNA, students also needed to understand the structure of RNA, and how DNA would provide instructions for the manufacture of the components required in transcription and translation, and for protein synthesis (Table 2).

\section{Comprehension of concepts on RNA and protein synthesis}

The syllabus (Table 2) indicated that students needed to be knowledgeable on the flow of the genetic message from DNA to RNA to protein. Like the findings for DNA content, students had 
a superficial understanding of RNA concepts, even though the syllabus indicated that this knowledge was considered background to new concepts to be taught (Table 2). Students understood the basic concept regarding the flow of the genetic message, as can be seen by $93.8 \%$ of participants correctly responding to the question below (example 6). Most students also understood base-pairing rules for transcription, as $89.3 \%$ correctly answered this type of question (example 7):

Example 6: The flow of information in a cell proceeds in what sequence?

- $\quad$ *From DNA to RNA to protein

- From protein to RNA to DNA

- From RNA to DNA to protein

- From DNA to protein to RNA

Example 7: A particular triplet of bases in the template strand of DNA is 5'-AGT-3'. What would be the corresponding codon for the mRNA that is transcribed?

- *3'-UCA-5'

- $3^{\prime}-U G A-5$

- 3'-ACU-5'

- $5^{\prime}-\mathrm{TCA}^{\prime} 3^{\prime}$

However, on closer examination it becomes clear that students may not have necessarily grasped the processes associated with transcription and translation, since only $26.4 \%, 67.5 \%$, and $60.5 \%$ correctly responded to the following questions (examples $8,9,10$ ) respectively:

Example 8: A particular triplet of bases in the coding strand of DNA is AAA. The anticodon on the tRNA that binds this mRNA codon is

- $\quad * U U U$

- UUA

- TTT

- AAA

Example 9: Which of the following processes occurs during transcription?

- mRNA attaches to ribosomes.

- DNA is replicated.

- Proteins are synthesised.

- $\quad *$ RNA is synthesised. 
Example 10: Which of the following molecules are required for the process of translation?

- mRNA, tRNA and DNA

- mRNA, tRNA, DNA and rRNA

- $\quad * m R N A$, tRNA, and rRNA

- $\quad$ mRNA, DNA, and rRNA

Moreover, students could have looked at the process of transcription and translation in a compartmentalised manner, i.e., while they were able to correctly identify base-pairs for the mRNA strand and the associated amino acids for the codons (example 11), they struggled when this same concept required that they work out the DNA strand based on the amino acid chain (example 12).

Example 11: What amino acid sequence will be generated, based on the following mRNA codon sequence?

5'-AUG-UCU-UCG-UUA-UCC-UUG-3'

$74.8 \%$ answered correctly.

- met-ser-leu-ser-leu-ser

- *met-ser-ser-leu-ser-leu

- met-arg-glu-arg-glu-arg

- met-glu-arg-arg-glu-leu

Example 12: Which of the following sequences of nucleotides are possible in the template strand of DNA that would code for the polypeptide sequence Phe-Leu-Ile-Val?

$60.5 \%$ answered correctly.

- 5'-TTG-CTA-CAG-TAG-3'

- 5'-AUG-CTG-CAG-TAT-3'

- *3'-AAA-GAA-TAA-CAA-5'

- 3'-AAA-AAT-ATA-ACA-5'

This analysis shows that the students' prior knowledge on RNA synthesis listed in the syllabus was not aligned with their understandings when they entered first-year biology. While the examples above illustrate the knowledge gaps and depth of understanding present in prior 
knowledge, the section which follows provides detail on the mark allocation and correct responses per question type for the tests.

\section{Students' response to different question types}

It could be that while at the procedural level students were able to do simple calculations, they were still not making meaning of the content on DNA and RNA synthesis. The analysis of data showed that the majority of students correctly responded to questions which covered factual material (Table 3). However, fewer students were able to correctly answer conceptual and procedural type questions (Table 3). Students generally fared better on recall and understandingtype questions compared to ones which required analysis (Table 3).

Table 3: Mark allocation in relation to marks attained for test questions

\begin{tabular}{|c|c|c|c|c|c|c|c|c|}
\hline & \multicolumn{4}{|c|}{$\begin{array}{l}\text { Marks allocated for different types of } \\
\text { questions }\end{array}$} & \multicolumn{4}{|c|}{$\begin{array}{l}\text { Average \% of correct responses to the } \\
\text { different types of questions }\end{array}$} \\
\hline & $\begin{array}{c}1 \\
\text { Recall }\end{array}$ & $\begin{array}{c}2 \\
\text { Under- } \\
\text { standing }\end{array}$ & $\begin{array}{c}3 \\
\text { Analysis }\end{array}$ & $\begin{array}{l}\text { Total per } \\
\text { know- } \\
\text { ledge } \\
\text { dimen- } \\
\text { sion }\end{array}$ & $\begin{array}{c}1 \\
\text { Recall }\end{array}$ & $\begin{array}{c}2 \\
\text { Under- } \\
\text { standing }\end{array}$ & $\begin{array}{c}3 \\
\text { Analysis }\end{array}$ & $\begin{array}{c}\text { Total per } \\
\text { know- } \\
\text { ledge } \\
\text { dimen- } \\
\text { sion }\end{array}$ \\
\hline 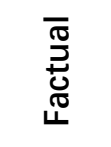 & 16 & 4 & 3 & 25 & 65,9 & 67,6 & 71,1 & 68,2 \\
\hline 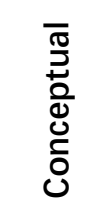 & 10 & 11 & 4 & 23 & 61,1 & 58,6 & 55,9 & 58,5 \\
\hline 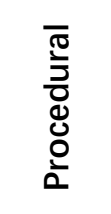 & 1 & 2 & 10 & 13 & 70 & 62,8 & 42,1 & 58,7 \\
\hline $\begin{array}{l}\text { Total } \\
\text { per } \\
\text { cog- } \\
\text { nitive } \\
\text { level }\end{array}$ & 27 & 17 & 17 & & 65,7 & 63 & 56,4 & \\
\hline
\end{tabular}

The quick insights offered by the students' responses to the online multiple-choice tests provided access to their level of relevant prior knowledge for threshold concepts to be taught in the course. This information was compared to the expectations of prior knowledge laid out in the syllabus. The insights gained from these comparisons made the lecturer aware of the students' needs. 
Constructive alignment theory indicates that teachers need to operationalise what student understanding means in relation to the delivery of the curriculum. My research shows that this view is particularly significant if the teacher intends to move students from lower cognitive levels, such as understanding by memorisation, to higher cognitive levels such as being able to apply the knowledge learnt. This links in with Biggs's view that if students understand content at a higher cognitive level they would act differently when interacting with the content as they proceed with their learning. In the context of my research, students needed instructional assistance (discussed next) to move from remembering to applying information. It is necessary to identify the gaps between what students know, what prior knowledge the syllabus expects, and what lecturers do when they teach, in order to achieve constructive alignment in this context.

Intervention to mitigate knowledge gaps identified by student responses to assessments Drawing on students' responses to the prior knowledge tests, I redesigned my lecture material, slides, and questions for discussion that I could pose during lectures and ones that I provided as homework exercises. I also converted some of my lecture slots into tutorial-type lessons, which included a mix of multiple-choice and short paragraph questions. The questions came from areas of challenge exposed in the prior knowledge tests. During class discussions I also illustrated the difference between recall, conceptual, and procedural-type questions. This approach was aimed to provide students with insight into different types of questions they could expect on assessments in the higher education context.

Since findings indicated that students had difficulty with visualising the process of DNA replication, I included a step-by-step instruction on building a DNA model. This hands-on activity was meant to provide students with the opportunity to think about how DNA replication occurs based on its structure.

These different measures required me to rethink my teaching practice and approach within this context; however, this was a necessary step so that closer alignment could occur between the prior knowledge of the cohort and the expectations laid out in the syllabus. In other words, for learning to be optimised, this form of curriculum modification and delivery was necessary.

\section{Integrated Discussion}

To effectively engage with students, it is necessary to understand the quality of knowledge students have when they enter the course (Ambrose and Lovett, 2014). Meaning-making during learning is best stimulated when the needs of students are identified and met in learning-centred teaching (Dennick, 2016), which is part of the process for constructive alignment (Biggs and Tang, 2007). This section reflects on how the analysis of the students' responses to the online multiplechoice tests can be used as a tool to gain insight into the understandings they have in relation to course expectations; the value of the lecturer's response to narrowing the gap between what students know and are expected to know when they enter a course and as a mechanism to provide quality teaching to large first-year classes. 


\section{What students know and what is required by the course syllabus}

Learning is a process that is constructive in its nature and occurs through the building of new knowledge based on current knowledge structure (Hattie and Yates, 2014). Bearing in mind that students look for cues on the type of study approach which will enable them to pass or achieve a 'good' grade (Luckett and Sutherland, 2000), much thought and planning needs to be given to how students' responses to assessments early in the year can impact on good practice in the classroom. Therefore, it is imperative that lecturers look at how pedagogic practice influences student learning. For example, the lecturer gained insight into the depth of the students' knowledge on DNA and RNA synthesis from the online tests. This knowledge was meant to help close the gap between what students were expected to know and did know.

Effective teaching is associated with the refinement of students' understanding: an active and engaged lecturer can create an environment to actively engage students. This study's findings indicate that when the lecturer uses students' responses to online multiple-choice tests to direct the preparation for class, this addresses the students' knowledge gaps in a focused and direct manner and strengthens the students' position to grasp threshold concepts. This study contributes to existing literature by showing that the use of online multiple-choice tests on prior knowledge administered early in the year has proven value for the construction of instructional materials according to the needs of the students. The provision of individualised and personalised lectures, implied in studies such as those by Luckett and Sutherland (2000), is, however, challenging with large classes.

\section{Individualised and personalised lectures: Is this a reasonable ask for the large class situation?}

The reality at most universities is that class sizes are increasing, especially at undergraduate level. The question that arises then is: How does a lecturer monitor learning at the level of the individual, and provide individualised lectures targeted at specific problem areas, whilst economising on the time and effort required to manage learning at this level? The findings in this study show that it is possible for the lecturer to gain insights into students' understanding at the start of a course and use it to prepare personalised lectures that address the specific cohort's needs. This requires that lecturers be aware of the level of background knowledge related to threshold concepts that must be understood to fulfil learning outcomes (Richmond, et al., 2016). Hattie (2015) suggests that to move students to a deeper approach to learning, more is needed than only speaking to the class during a lecture. My study shows that the lecturer can discover the students' knowledge gaps by testing their prior knowledge and use this understanding to influence the way in which the curriculum is delivered in order to enrich the learning environment. As much as student quality of engagement and learning lies in the hands of the learners (Biggs, 1996), lecturers can find the means to actively encourage students in this engagement. However, for instructional design to meet this aim, it is necessary to find out what level of understanding students have already achieved. Biggs' (1996) notion of constructive alignment indicates that teachers need to explicitly indicate to students the intended learning outcomes. This study 
expands on this view by showing that it is also necessary for teachers to be knowledgeable on what prior knowledge foundations students have, so that this foundation can be built on during instruction design and classroom practices.

Anecdotal discussions often refer to the lack of preparation of school leavers for university, and that there is not sufficient space in the first-year curriculum to provide for this apparent lack of knowledge. However, this study has shown that by considering the curriculum and intended learning outcomes as a flexible area, it is possible to adapt one's teaching practices to meet the learning outcomes of the syllabus. Such practices will provide for a more enriched learning environment for first years.

\section{Final words}

In the literature review and conceptual framework section I outlined Biggs's (2003) four stages to constructive alignment. My study proposes an additional step. Prior to Biggs's step 1 of setting intended learning outcomes, a step is required to unravel the relevant foundational knowledge students have in relation to the expectations of the prescribed syllabus. Once lecturers have this insight, they need to determine whether the intended learning outcomes need to be adapted in any way to meet the cohort's needs. Biggs claims that when we teach, we need to have a clear view of what it is that we want students to learn. Through the investigations in this study, I argue that it is equally important to understand what knowledge students have when they enter the course. Once this has been revealed to the lecturers, only then can teaching practices be aligned to the needs of the students, the curriculum, the learning activities and intended outcomes.

\section{Limitations}

Considering that students answered tests outside contact time, it is possible that some worked with peers and/or used sources such as the textbook or the internet to find responses to questions. Additionally, questions were not randomised, and this could have influenced the responses. However, it is hoped that since students were aware that the grades did not count as a summative assessment, and were meant to inform lecturer practice only, this limitation was mitigated. More depth to our understanding can be gained if we survey students to understand the approaches they used for their learning. This could tie in with the results that show students find it difficult to apply concepts which they remember or have a prior understanding about. This can be considered as territory for future research.

\section{Conclusion}

The syllabus provides the student with the intended curriculum and indicates the prior knowledge required when they enter a course. Using tests to assess students' level of prior knowledge, this study shows 1 ) the mismatch between the expected prior knowledge listed in the syllabus, and the students' actual level of comprehension, and 2) how lecturers can use online tests to gauge students' level of understanding. As demonstrated in this paper, these insights can be used to prompt lecturers about knowledge and can facilitate their preparation to suit the class's needs. 
Constructive alignment recognises that teaching acts as a catalyst for learning. This study highlights that for this to be a reality, lecturers need to be conscious of the needs of the cohort. This means that lecturers need to be aware of their students' foundational knowledge if they are to set up learning environments that meet the needs of the desired outcomes.

Within the South African context, where there is a persistent and mounting call for transformation of the education system, it is of paramount importance that the massification of education does not lead to a dilution of its quality. Whereas the curriculum is generally presented as a fixed signifier of content that needs to be covered, lecturers hold the key to the extent to which student learning can be enriched by means of pedagogic practice, even for large and diverse classes. The author's method to analyse prior knowledge in biology would be applicable to other similar courses. If the primary objective of gaining a university qualification is to provide an intellectual economy for South Africa, then it is necessary to focus on enriching the learning opportunities available to our students by determining the level of their relevant prior learning, especially for first year students with their diverse school backgrounds and preparedness for university.

\section{Author Biography}

Shalini Dukhan is a Senior Lecturer in School of Animal, Plant and Environmental Sciences at University of the Witwatersrand, South Africa. Her research interests are in examining factors that impact on the development of Science Identity among biology students and how this influences their learning and academic achievement.

\section{References}

Ambrose, S A. \& Lovett, M. C. 2014. Prior-knowledge is more important than content: Skills and beliefs also impact learning. In Benassi, V.A., Overson C. E. \& M. Hakala, C. (eds.) Applying Science of Learning in Education: Infusing Psychological Science into the Curriculum. Available at: http://teachpsych.org/ebooks/asle2014/ index.php (Accessed: 14 September 2021).

Armbruster, P., Patel, M., Johnson, E. \& Weiss, M. 2009. Active learning and student-centered pedagogy improve student attitudes and performance in Introductory Biology. CBE Life Sciences, 8(3): 203-213.

Baird, J., Andrich, D., Hopfenbeck, T.N. \& Stobart, G. 2017. Assessment and learning: fields apart? Assessment in Education: Principles, Policy and Practice, 24(3): 317-350.

Baleni, Z. 2015. Online formative assessment in higher education: Its pros and cons. The Electronic Journal of e-Learning,13(4): 228-235.

Biggs, J. 1996. Enhancing teaching through constructive alignment. Higher Education, 32: 347364.

Biggs, J. 2003. Aligning Teaching for Constructing Learning. York, UK: Higher Education Academy.

Biggs, J. \& Tang, C. 2007. Teaching for Quality Learning at University: What the Student Does. New York, NY: McGraw-Hill. 
Boud, D \& Falchikov, N. (eds.). 2007. Rethinking assessment in higher education. Oxford, UK: Routledge.

Braun, V. \& Clarke, V. 2006. Using thematic analysis in psychology. Qualitative Research in Psychology, 3: 77-101.

Carless, D. 2015. Exploring learning-oriented assessment processes. Higher Education, 69: 963976.

Coley, J.D. \& Tanner, K. 2015. Relations between intuitive biological thinking and biological misconceptions in biology majors and nonmajors. CBE-Life Sciences, 14: 1-19.

Dennick, R. 2016. Constructivism: Reflections on twenty-five years teaching the constructivist approach in medical education. International Journal of Medical Education, 7: 200-205.

Dukhan, S. 2018. Note-making In Biology: How the school experience influences note-making practice and approach at university. African Journal of Research in Mathematics Science and Technology Education, 22(3): 265-275.

Evans, C., Howson, C.K. \& Forsythe, A. 2018. Making sense of learning gain in higher education. Higher Education Pedagogies, 3(1): 1-45.

Hattie, J.H. 2015. The applicability of visible learning to higher education. Scholarship of Teaching and Learning in Psychology, 1(1): 79-91.

Hattie, J.A.C., \& Yates, G.C.R. 2014. Using feedback to promote learning. In Benassi, V.A., Overson, C.E. \& Hakala, C.M. (eds.) Applying Science of Learning in Education: Infusing Psychological Science into the Curriculum. Available at: http://teachpsych.org/ebooks/asle2014/index.php (Accessed: 14 September 2021).

Kelly-Laubscher, R. \& Van Der Merwe, M. 2015. An intervention to improve academic literacies in a first-year university biology course. Critical Studies in Teaching and Learning (CriSTaL), 2(2): 1-23.

Kember, D. \& Kwan, K. 2000. Lecturers' approach to teaching and their relationship to conceptions of good teaching. Instructional Science, 28: 469-490.

Luckett, K., \& Sutherland, L. 2000. Assessment practices that improve teaching and learning. In Makoni, S. (ed.) Teaching and Learning in Higher Education: A Handbook for Southern Africa. Johannesburg: Witwatersrand University Press, 98-130.

Mccomas, W.F., Reiss, M.J., Dempster, E., Lee, Y.C., Olander, C., Clement, P., Borewinkel, D.J. \& Waarlo, A.J. 2018. Considering grad challenges in biology education: Rationales and proposals for future investigations to guide instruction and enhance student understanding in the life sciences. The American Biology Teacher, 80(7): 483-492.

Meyer, J.H.F. \& Land R. 2005. Threshold concepts and troublesome knowledge: Epistemological considerations and a conceptual framework for teaching and learning. Higher Education, 49(3): 373-388.

Morrison, S. \& Free, K.W. 2001. Writing multiple-choice items that promote and measure critical thinking. Journal of Nursing Education, 40(1): 17- 24. 
Moravec, M., Williams, A., Aguilar-Roca, N. \& O'Dowd, D. K. (2010). Learn before lecture: a strategy that improves learning outcomes in a large introductory biology class. CBE Life Sciences Education, 9, 473-481.

Prevost, L.B., Smith, M.K. \& Knight, J.K. 2016. Using student writing and lexical analysis to reveal student thinking about the role of stop codons in the central dogma. CBE-Life Sciences Education, 15(4): 1-13.

Richmond, A. S., Slattery, J., Morgan, R. K., Mitchell, N. \& Becknell, J. 2016. Can a learner-centered syllabus change student's perceptions of student-professor rapport and master teacher behaviors? Scholarship of Teaching and Learning in Psychology, 2: 159-168.

Sobuwa, S. \& McKenna, S. 2019. The obstinate notion that higher education is a meritocracy. Critical Studies in Teaching and Learning (CriSTaL), 7(2): 1-15.

Van den Broek, P. \& Kendeou, P. 2008. Cognitive processes in comprehension of Science texts: the role of co-activation in confronting misconceptions. Applied Cognitive Psychology, 22(3): 335-351.

Van Loon, M.H., Dunlosky, J., van Gog, T., Merriënboer, J.J.G. \& de Bruin, A.B.H. 2015. Refutations in science texts lead to hypercorrection of misconceptions held with high confidence. Contemporary Educational Psychology, 42: 39-48.

Wang, X., Su, Y., Cheung, S., Wong, E. \& Kwong, T. 2013. An exploration of Biggs' constructive alignment in course design and its impact on students' learning approaches. Assessment and Evaluation in Higher Education, 38(4): 477-491.

Wright, L.K., Fisk, J.N., \& Newman, D.L. 2014. DNA $\rightarrow$ RNA: What do students Think the Arrow Means? CBE-Life Sciences Education, 13(2): 338-348. 